\title{
A COMPARATIVE STUDY OF ATTITUDES OF ADOLESCENTS STUDYING IN JUNIOR COLLEGES OF RURAL AND URBAN AREAS OF BIJAPUR TOWARDS EDUCATIONAL AND NUTRITIONAL ASPECTS OF LIFE
}

\author{
Sadashiva Basavantappa Ukkali1, Nagamani Mohan Rao Kulkarni², Mohammed Zeeshan Desai ${ }^{3}$, Khodaija Mahvish4, Umme Uzra ${ }^{5}$ \\ Ayesha Siddiqa ${ }^{6}$
}

${ }_{1}$ Associate Professor, Department of Paediatrics, Al Ameen Medical College Hospital, Bijapur, Karnataka, India. ${ }_{2}^{2}$ Assistant Professor, Department of Paediatrics, Al Ameen Medical College Hospital, Bijapur, Karnataka, India. ${ }_{3}^{3}$ Postgraduate Student, Department of Paediatrics, Al Ameen Medical College Hospital, Bijapur, Karnataka, India. ${ }_{4}^{4}$ Postgraduate Student, Department of Paediatrics, Al Ameen Medical College Hospital, Bijapur, Karnataka, India. ${ }^{5}$ Postgraduate Student, Department of Paediatrics, Al Ameen Medical College Hospital, Bijapur, Karnataka, India. ${ }^{6}$ Postgraduate Student, Department of Paediatrics, Al Ameen Medical College Hospital, Bijapur, Karnataka, India.

BBSTRACT
Adolescent period is a time of considerable change in all aspect of functioning. There are three aspects of significant concern during
adolescence, viz. educational change drastically due to rapid increase in physical growth and hard struggle to adjust mentally, both
of which stabilise towards late adolescence.

\section{MATERIALS AND METHODS}

Total of 1000 adolescents 16 - 18 yrs., 250 each from 4 PU Colleges (2 Urban + 2 Rural) were interviewed using a pre-tested questionnaire. Based on responses, their attitude towards educational and nutritional aspects of life were assessed, analysed and compared.

\section{RESULTS}

Academic underachievement was more common in rural adolescents; nutritional status and dietetic practices and beliefs of the 2 groups differed significantly.

\section{CONCLUSION}

Varieties of attitudes were observed in adolescents of urban and rural colleges. Risk taking behaviour was more common in urban adolescents because of high peer pressure, curiosity and more exposure to mass media. Academic underachievement in rural set-up was because of lack of facilities and motivation, nutrient consumption was significantly lower than RDA in both the groups because of lack of knowledge about redistribution of nutrients and unawareness of suitable ways to meet their nutritional status.

\section{KEY WORDS}

Adolescent; Attitude; Urban; Rural; Educational; Nutritional.

HOW TO CITE THIS ARTICLE: Ukkali SB, Kulkarni NMR, Desai MZ, et al. A comparative study of attitudes of adolescents studying in junior colleges of rural and urban areas of Bijapur towards educational and nutritional aspects of life. J. Evolution Med. Dent. Sci. 2018;7(46):4970-4976, DOI: 10.14260/jemds/2018/1106

\section{BACKGROUND}

'Adolescence' the period between 10 and 19 years of age is understood in different ways in different cultures. ${ }^{1}$ It is difficult to clearly define the boundaries of adolescents and determine the parameters with which to measure those boundaries, as it is no wonder clinicians may find legal status of this age group a challenge. ${ }^{2}$ It is a period of temporary maladjustments. During this period adolescents develop attitudes, values and behaviours that will carry them to adulthood. ${ }^{3}$ There are three aspects of significant concerns during adolescence, viz. educational and nutritional. By the adolescent one has to face leaving school and moving towards further education earning and financial independence or unemployment. ${ }^{4}$

'Financial or Other Competing Interest': None.

Submission 22-07-2017, Peer Review 23-06-2018,

Acceptance 01-07-2018, Published 12-11-2018.

Corresponding Author:

Sadashiva Basavantappa Ukkali,

Associate Professor,

Department of Paediatrics,

Al Ameen Medical College Hospital,

Bijapur, Karnataka, India.

E-mail: saduukkali@yahoo.co.in

DOI: $10.14260 /$ jemds/2018/1106
It is unfortunate that importance of balanced nutrition needed in this critical period of rapid growth and lifestyle adopted by adolescence leads to problems of obesity and eating disorder which have a bearing on adult life. 5 The behavioural problems in adolescence normally revolve around parents, peers, school and colleges, employment issues and health. ${ }^{6}$ Thus, the current study is to know and compare the attitudes of adolescents in junior colleges of rural and urban areas of Bijapur towards educational and nutritional aspects of life.

\section{Aims and Objectives}

1. To know the attitudes of adolescent studying in junior colleges of rural and urban areas of Bijapur towards educational and nutritional aspects of life.

2. To compare the attitudes of adolescents studying in junior colleges of rural and urban areas of Bijapur towards educational and nutritional aspects of life.

\section{MATERIALS AND METHODS}

Inclusion Criteria

- Adolescents between 16 and 18 yrs. of age.

- Studying in first and second PUC. 
- Late adolescent 16 to 18 yrs. are chosen as they have fully formed ideas, well-formed opinions and distinct identity.

\section{Exclusion Criteria}

- Those who are not willing for the study.

- $\quad$ Those who are Hostel residents.

\section{Type of Study}

Comparative cross-sectional survey conducted among adolescents studying in rural and urban junior college of Bijapur.

\section{Study Population/ Sample Size}

A total of 1000 adolescents (age group 16 - 18 years), 500 each from rural and urban college of Bijapur were taken for convenience for our study. They were interviewed using a pretested questionnaire. To ensure equal distribution from rural and urban areas, we have chosen 500 each as educational aspect and nutritional aspects of life differ from rural and urban area. Based on responses their attitude towards educational and nutritional aspect of life were assessed, analysed and compared.

\section{The Colleges Chosen were-}

Urban

- $\quad$ PDJ PU College, Bijapur.

- $\quad$ SECAB PU College, Bijapur.

\section{Rural}

- PU College, Managoli.

- Govt. PU College, Honnutagi.

\section{Methodology}

The study was conducted in the above rural and urban junior colleges of Bijapur. The aims and objectives of the study were explained to the college authorities and the permission was obtained from the principals of the colleges. Study was conducted during college hours. All the students in the class present on the day of interview were enrolled for the study. The purpose of the study was explained to the students and their consent was obtained.

A pretested, self-designed, semi-structured questionnaire was used. The questionnaire in English was translated and explained in Kannada also. After brief introduction, explanation of the purpose of work, students were asked to fill the questionnaire at a time so that all doubts of students could be attended to. Students were informed that participation was optional and that information was anonymous.

Students were told about questionnaire, its contents and method to fill the questionnaire. Though all questions were compulsory, when they did not answer a particular question they were not forced. They were asked to answer every question individually without any hesitation and without consulting each other and give their fair responses. Confidentiality was ensured. Supervision by the teachers was avoided to enable the students to answer the questions freely.

\section{Statistical Analysis}

All characteristics were summarised descriptively. For continuous variables, the summary statistics of mean was used. For categorical data, the number and percentage were used in the data summaries. Chi-square $\left(\chi^{2}\right) /$ Freeman-Halton Fisher exact test was employed to determine the significance of differences between groups for categorical data. Student's ' $t$ ' test is used to compare the energy and protein intakes of rural and urban adolescents. If the p-value was $<0.05$ then the results were considered to be statistically significant, otherwise it was considered as not statistically significant. Data were analysed using SPSS software v 23.0 and Microsoft Office.

\section{RESULTS}

\section{Personal Data}

\begin{tabular}{|c|c|c|c|}
\hline Age (Years) & Rural (\%) & Urban (\%) & P value \\
\hline 16 & $223(44.6)$ & $321(64.2)$ & \multirow{2}{*}{$<0.001$} \\
\cline { 1 - 3 } 17 & $164(32.8)$ & $147(29.4)$ & \\
\cline { 1 - 3 } 18 & $113(22.6)$ & $32(6.4)$ & \\
\cline { 1 - 3 } Total & $\mathbf{5 0 0}$ & $\mathbf{5 0 0}$ & \\
\cline { 1 - 2 } Table 1. Age Wise distribution of Adolescents \\
\hline
\end{tabular}

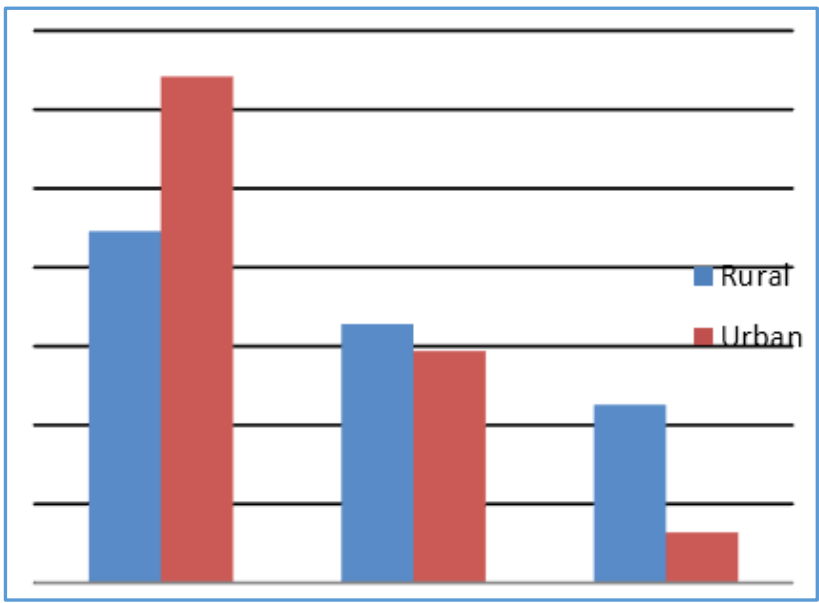

Graph 1. Age Wise distribution of Adolescents

\begin{tabular}{|c|c|c|c|}
\hline Sex & Rural (\%) & Urban (\%) & P value \\
\hline Male & $236(47.2)$ & $212(42.4)$ & \multirow{3}{*}{$>0.05$} \\
\hline Female & $264(52.8)$ & $288(57.6)$ & \\
\hline Total & 500 & 500 & \\
\hline
\end{tabular}

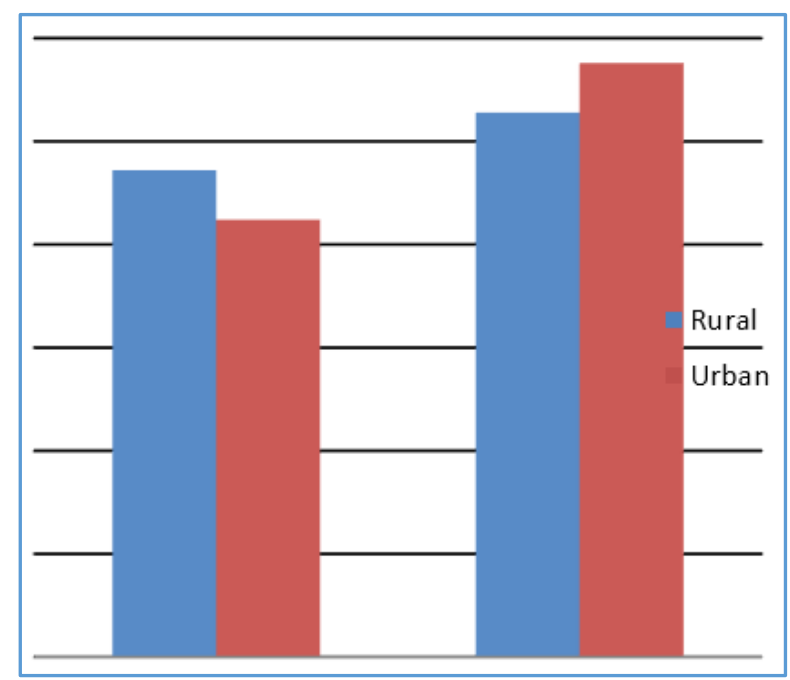

Graph 2. Sex Wise distribution of Adolescents 


\begin{tabular}{|c|c|c|c|c|c|}
\hline \multirow{2}{*}{$\begin{array}{c}\text { Age } \\
\text { (Years) }\end{array}$} & \multirow{2}{*}{ Sex } & \multicolumn{2}{|c|}{ Rural } & \multicolumn{2}{c|}{ Urban } \\
\cline { 3 - 6 } & & $\begin{array}{c}\text { Height } \\
\text { (cm) }\end{array}$ & $\begin{array}{c}\text { Weight } \\
\text { (kg) }\end{array}$ & $\begin{array}{c}\text { Height } \\
\text { (cms) }\end{array}$ & $\begin{array}{c}\text { Weight } \\
\text { (kg) }\end{array}$ \\
\hline \multirow{2}{*}{16} & Male & 153.5 & 38.5 & 158.06 & 47.95 \\
\cline { 2 - 6 } & Female & 150.4 & 39.0 & 150.08 & 44.92 \\
\hline \multirow{2}{*}{17} & Male & 159 & 42.1 & 163.15 & 48.45 \\
\cline { 2 - 6 } & Female & 151.2 & 41.3 & 150.86 & 46.86 \\
\hline \multirow{2}{*}{18} & Male & 161.2 & 46.0 & 164.45 & 52.45 \\
\cline { 2 - 6 } & Female & 152.1 & 42.8 & 152.23 & 47.0 \\
\hline
\end{tabular}

Table 3. Mean Anthropometric Measurement of Adolescent

\begin{tabular}{|c|c|c|c|}
\hline BMI & Rural (\%) & Urban (\%) & P-value \\
\hline$<=18.49$ & $210(42)$ & $105(21)$ & \multirow{4}{*}{$<0.001$} \\
\hline 18.5-24.99 & $257(51.4)$ & $298(59.6)$ & \\
\hline $25.0-29.99$ & $23(4.6)$ & $60(12)$ & \\
\hline$>=30$ & $10(2)$ & $37(7.4)$ & \\
\hline \multicolumn{4}{|c|}{ Table 4. Body Mass Index (BMI) } \\
\hline
\end{tabular}

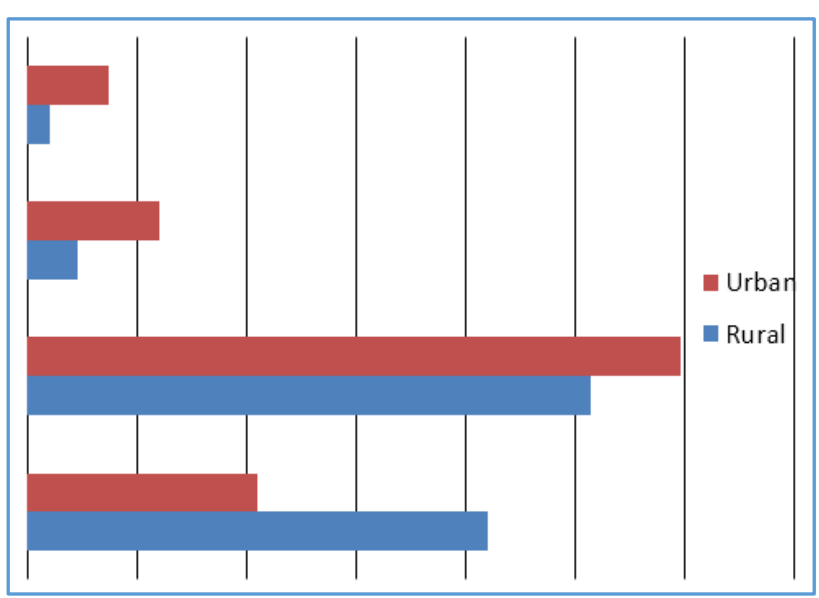

Graph 3. Distribution of Adolescents depending on BMI

\begin{tabular}{|c|c|c|c|}
\hline Criteria & Rural (\%) & Urban (\%) & P-value \\
\hline$>80 \%$ & $116(23.2)$ & $140(28)$ & $>0.05$ \\
\hline $60-80 \%$ & $180(36)$ & $266(53.2)$ & $<0.001$ \\
\hline$<60 \%$ & $204(40.8)$ & $94(18.8)$ & $<0.001$ \\
\hline
\end{tabular}

Table 5. Comparison of Grade Point Average of Adolescents

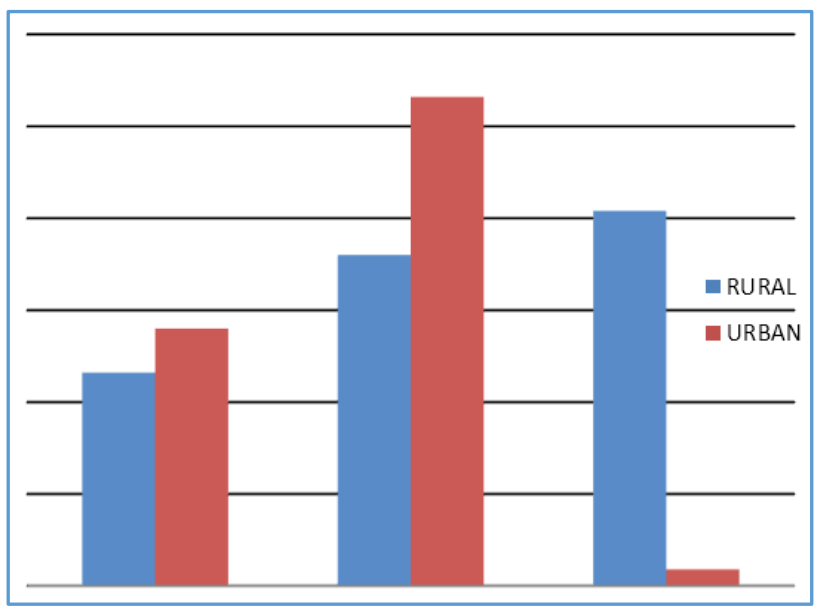

Graph 4. Comparison of Great Point Average of Adolescents

\begin{tabular}{|c|c|c|c|}
\hline Criteria & Rural (\%) & Urban (\%) & P-value \\
\hline Self study & $368(73.6)$ & $304(60.8)$ & \multirow{2}{*}{$<.001$} \\
\cline { 1 - 1 } $\begin{array}{c}\text { Discussion } \\
\text { with friends }\end{array}$ & $132(26.4)$ & $196(39.2)$ & \\
\hline \multicolumn{3}{|c|}{ Table 6. Comparison of Method of Study of Adolescents } \\
\hline
\end{tabular}

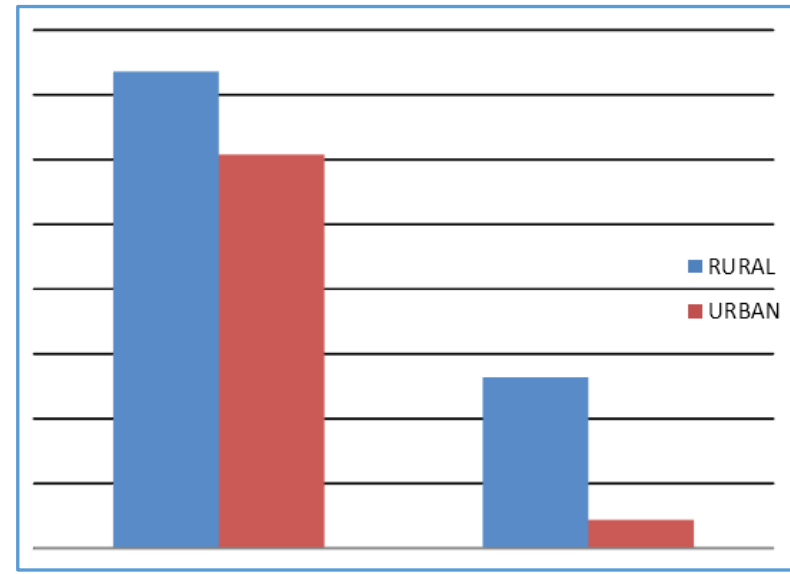

Graph 5. Comparison of Method of Study of Adolescents

\begin{tabular}{|c|c|c|c|}
\hline Criteria & Rural (\%) & Urban (\%) & P-value \\
\hline Vegetarian & $269(53.8)$ & $299(59.8)$ & \multirow{2}{*}{$<0.001$} \\
\hline Non-Vegetarian & $231(46.2)$ & $201(40.2)$ & \\
\hline \multicolumn{4}{|c|}{ Table 7. Distribution of Adolescents depending on their } \\
Choice of Food \\
\hline
\end{tabular}

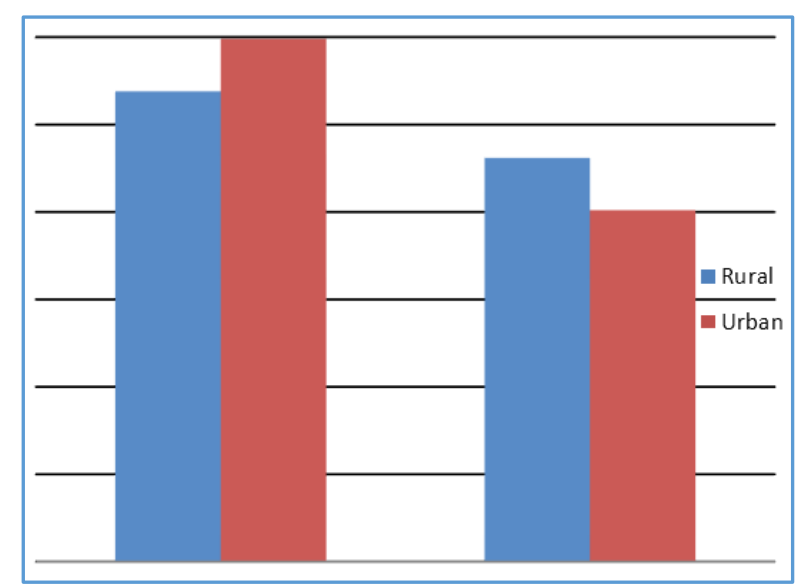

Graph 6. Distribution of Adolescents depending on their Choice of Food

\begin{tabular}{|c|c|c|c|}
\hline Criteria & Rural (\%) & Urban (\%) & P-value \\
\hline Overweight & $34(6.8)$ & $37(7.4)$ & $>0.50$ \\
\hline Right weight & $235(47)$ & $331(66.2)$ & $<0.001$ \\
\hline Underweight & $114(22.8)$ & $78(15.6)$ & $<0.005$ \\
\hline Do not know & $117(23.4)$ & $54(10.8)$ & $<0.001$ \\
\hline \multicolumn{4}{|c|}{ Table 8. Comparison of Perception of Weight Status of } \\
Adolescents
\end{tabular}

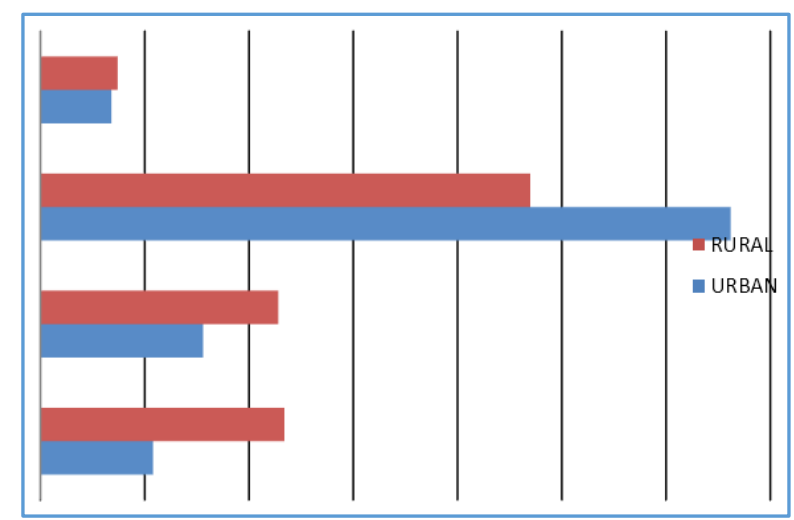

Graph 7. Comparison of Perception of Weight Status of Adolescents 


\begin{tabular}{|c|c|c|c|c|c|}
\hline Parameter & Criteria & Rural & Urban & $\mathrm{X} 2$ & P-value \\
\hline Class & $\begin{array}{l}\text { PUC } 1 \\
\text { PUC } 2 \\
\end{array}$ & $\begin{array}{l}321(64.2) \\
179(35.8)\end{array}$ & $\begin{array}{l}305(61) \\
195(39)\end{array}$ & 1.092 & $>0.10$ \\
\hline Grade Pt. Avg. & $\begin{array}{l}>80 \% \\
60-80 \% \\
<60 \%\end{array}$ & $\begin{array}{c}116(23.2) \\
180(36) \\
204(40.8)\end{array}$ & $\begin{array}{c}140(28) \\
266(53.2) \\
94(18.8)\end{array}$ & $\begin{array}{c}3.024 \\
29.932 \\
57.840\end{array}$ & $\begin{array}{l}>0.05 \\
<0.001 \\
<0.001\end{array}$ \\
\hline Failure in any class & & $44(8.8)$ & $21(4.2)$ & 8.703 & $<0.005$ \\
\hline Problem in attnd coll. & & $94(18.8)$ & $55(11)$ & 11.995 & $<0.001$ \\
\hline Bunking classes & $\begin{array}{c}\text { Often } \\
\text { Occasionally } \\
\text { Never }\end{array}$ & $\begin{array}{c}20(4) \\
73(14.6) \\
407(81.4)\end{array}$ & $\begin{array}{c}68(13.6) \\
91(18.2) \\
341(68.2)\end{array}$ & $\begin{array}{c}28.707 \\
2.362 \\
23.108\end{array}$ & $\begin{array}{c}<0.001 \\
>0.10 \\
<0.001\end{array}$ \\
\hline Problem conc. in class & & $118(23.6)$ & $127(25.4)$ & 0.437 & $>0.50$ \\
\hline $\begin{array}{c}\text { Studying daily lessons } \\
\text { on same day }\end{array}$ & & $41(8.2)$ & $101(20.2)$ & 29.545 & $<0.001$ \\
\hline Tuition & & $81(16.2)$ & $233(46.4)$ & 107.258 & $<0.001$ \\
\hline Method of study & $\begin{array}{c}\text { Self-Study } \\
\text { Discussion with friends }\end{array}$ & $\begin{array}{l}368(73.6) \\
132(26.4) \\
\end{array}$ & $\begin{array}{l}304(60.8) \\
196(39.2) \\
\end{array}$ & 18.582 & $<0.001$ \\
\hline Ambition & $\begin{array}{c}\text { Professional } \\
\text { Defence } \\
\text { Administration } \\
\text { Teacher } \\
\text { Others } \\
\text { Not decided } \\
\end{array}$ & $\begin{array}{c}128(25.6) \\
57(11.4) \\
77(15.4) \\
88(17.6) \\
121(20.2) \\
39(7.8) \\
\end{array}$ & $\begin{array}{l}174(34.8) \\
86(17.2) \\
56(11.2) \\
71(14.2) \\
96(19.2) \\
17(3.4) \\
\end{array}$ & $\begin{array}{l}10.037 \\
6.862 \\
3.823 \\
2.160 \\
3.678 \\
9.154 \\
\end{array}$ & $\begin{array}{l}<0.001 \\
<0.01 \\
>0.05 \\
>0.10 \\
>0.05 \\
<0.005\end{array}$ \\
\hline Feels safe at coll. & & $440(88)$ & $432(86.4)$ & 0.573 & $>0.10$ \\
\hline OP ON CO-ED & $\begin{array}{l}\text { Good } \\
\text { Okay } \\
\text { Bad }\end{array}$ & $\begin{array}{c}247 \\
162 \\
91 \\
\end{array}$ & $\begin{array}{c}371 \\
78 \\
51 \\
\end{array}$ & $\begin{array}{l}65.131 \\
38.684 \\
13.124 \\
\end{array}$ & $\begin{array}{l}<0.001 \\
<0.001 \\
<0.001\end{array}$ \\
\hline
\end{tabular}

\section{Attitude towards Educational Aspects}

- Adolescents studying in PUC 1 were more than those in PUC 2 in both rural and urban college.

- Majority of urban adolescents scored 60 - 80\% (R-36\%, U-53.2\%), whereas majority of rural adolescents scored $<60 \%$ (R-40.8\%, U-18.8\%).

- Adolescents who failed in any class were more in rural colleges (R-8.8\%, U-4.2\%).

- $\quad 18.85$ of rural adolescents had problem in attending college regularly as compared to only $11 \%$ of urban. There was a significant difference between the two groups regarding bunking of classes. $81.4 \%$ of rural adolescents never bunked classes as compared to $68.2 \%$ of urban adolescents.

- Only 5.3\% of rural adolescents bunked class as compared to $16.35 \%$ of urban, because of health problems. Boredom was the reason in $45.16 \%$ of rural and $35.22 \%$ of urban adolescents.

- Roaming around/ watching movie was the main reason in both the groups (R-49.4\%, U-48.42\%).

- $23.6 \%$ of rural and $25.4 \%$ of urban adolescents had problem in concentrating in class. $20.2 \%$ of urban adolescents studied daily lessons on the same day, while only $8.2 \%$ of rural adolescents did so.

- Significantly, large number of adolescents went for tuition as compared to rural (R-16.2\%, U-46.6\%).
- The reasons given for going to tuition were to score more marks (R-66.7\%, U-62.23\%), parental force (R-22.1\%, U$19.31 \%$ ) and no good teaching at college (R-11.1\%, U$18.45 \%)$.

- $73.6 \%$ of rural and $60.8 \%$ of urban adolescents liked selfstudy, while $26.4 \%$ of rural and $39.2 \%$ of adolescents liked discussion with friends/ group of friends.

- $70.4 \%$ of rural adolescents said teachers influenced positively, while only $57 \%$ of urban adolescents felt so.

- Physics subject and teacher were the favourites among science students in both the set-ups, while it was economics subject and teacher among the rest.

- Maximum number of adolescents wanted to become professionals in both the groups (R-25.6\%, U-34.8\%). The adolescents who chose to join defence were more in the urban group (R-11.4\%, U-17.2\%), but who chose administrative services and teaching were more in rural colleges.

- The two groups differed in their opinion about coeducation. $74.2 \%$ of urban adolescents as compared to only $49.4 \%$ of rural felt it to be good and $32.4 \%$ of rural and $15.6 \%$ urban adolescents felt it to be okay, but $15.2 \%$ of rural and $10.2 \%$ of urban adolescents hated coeducation.

\begin{tabular}{|c|c|c|c|c|c|}
\hline Parameter & Criteria & Rural & Urban & $\mathrm{X} 2$ & P-value \\
\hline No. of main meals per day & $\begin{array}{l}\leq 2 \\
\geq 3\end{array}$ & $\begin{array}{l}157(31.4) \\
343(68.6)\end{array}$ & $\begin{array}{l}256(51.2) \\
244(48.8)\end{array}$ & 40.426 & $<0.001$ \\
\hline Snacks & $\begin{array}{c}\text { Rarely } \\
\text { Sometimes } \\
\text { Often }\end{array}$ & $\begin{array}{c}249(49.8) \\
191(38.2) \\
60(12)\end{array}$ & $\begin{array}{l}133(26.6) \\
249(49.8) \\
118(23.6)\end{array}$ & $\begin{array}{l}56.998 \\
13.692 \\
22.990\end{array}$ & $\begin{array}{l}<0.001 \\
<0.01 \\
<0.001\end{array}$ \\
\hline Duration b/n each meal & $4-6$ hours & $29(5.8)$ & $17(3.4)$ & 3.280 & $>0.05$ \\
\hline
\end{tabular}




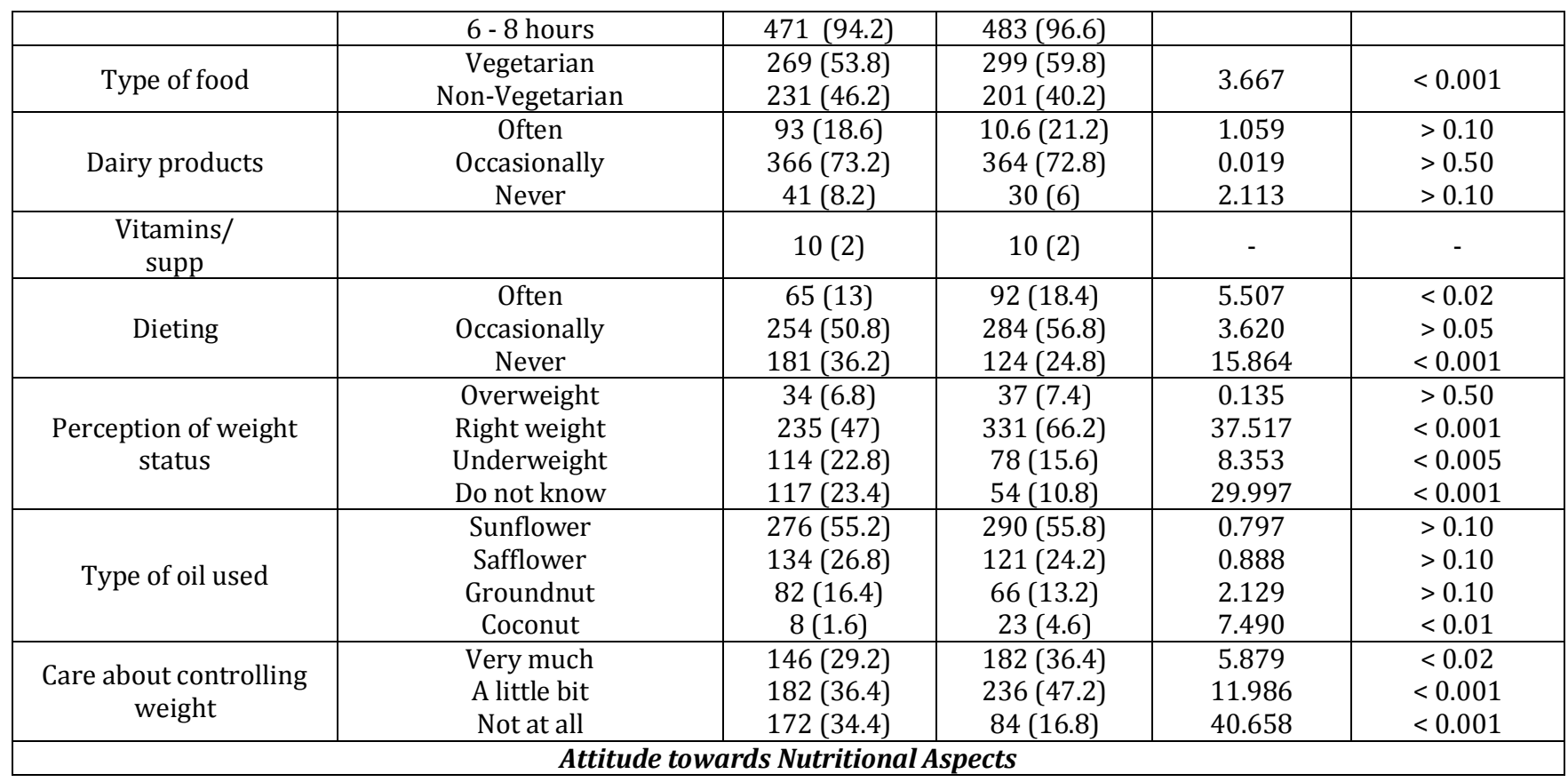

\section{Attitudes towards Nutritional Aspects}

- $\quad 51.2 \%$ of urban and $31.4 \%$ of rural had $\leq 2$ main meals per day in order to maintain their body shape, while $68.6 \%$ of rural and $48.8 \%$ of urban adolescents took 3 main meals per day. Mean energy intake was $1565 \mathrm{kcal}$ and $1815 \mathrm{kcal}$ in rural and urban adolescents respectively, whereas mean protein intake was $42 \mathrm{~g}$ and $46 \mathrm{~g}$ respectively. The two groups differed significantly in this respect.

- Snacking was more prevalent in urban adolescents.

- $\quad 94.2 \%$ of rural and $96.6 \%$ of urban adolescents said duration between each meal was 6 - 8 hours.

- Vegetarians constituted $53.8 \%$ of rural and $59.8 \%$ of urban adolescents.

- Significantly, more number of urban adolescents consumed milk everyday than rural.

- Only $2 \%$ from both groups took vitamin/ mineral supplements.

- $\quad$ Eating pizza was more common in urban adolescents (85.6 vs. 68.2\%) and more number of urban ate outside as compared to rural (75.2 vs. 61.8\%). Dieting was practiced by $75.2 \%$ urban compared to $63.8 \%$ rural adolescents.

- $66.2 \%$ urban and $47 \%$ of rural adolescents felt their weight was normal and $23.4 \%$ rural and $10.8 \%$ urban were unaware of their weight status.

- Majority of both groups used sunflower oil at their homes. Both groups differed slightly in their concern for weight control.

- $\quad 83.6 \%$ of urban and $65.6 \%$ of rural adolescents were concerned about weight control and $16.8 \%$ urban vs. $34.4 \%$ rural adolescents never bothered about their weight.

\section{DISCUSSION}

The was conducted to know and compare the attitudes of adolescents between 16 - 18 years of age studying in junior colleges of rural and urban areas of Bijapur towards educational and nutritional aspects of life.

\section{Attitude towards Educational Aspects} Class

In rural colleges, $64.2 \%$ were in PUC 1 and $35.8 \%$ were in PUC 2. The percentage for the same being $61 \%$ and $39 \%$ respectively in urban colleges.

\section{Grade Point Average}

Grade point average of $<60 \%$ was found in $40.8 \%$ of rural adolescents as compared to only $18.8 \%$ in urban adolescents.

\section{Failure in any Class}

Significantly, more number of rural adolescents had failed in one or the other class than urban adolescents. This is comparable to study done by MKC Nair.

\section{Problem in Attending College Regularly}

In contrast to the studies done by MKC Nair in which most students had no problem in attending colleges regularly, $18.8 \%$ of rural and $11 \%$ of urban adolescents in this study had problems in attending colleges regularly. The difference between the two groups was also significant.

\section{Bunking Classes}

Urban adolescents bunked classes more frequently than rural. The reasons for bunking classes were mainly to roam around/watch movies, because of boring classes and health problems.

\section{Problem Concentrating in Class}

The difference was not significant between rural and urban adolescents in this aspect though. In MKC Nair study, this problem was in $40 \%$ of adolescents which is quite high compared to our study.

\section{Studying Daily Lessons on the Same Day}

The difference between the two groups was significant in our study. 


\section{Going for Tuition}

A large number of urban adolescents went for tuition as compared to rural.

\section{Method of Study}

The percentage of adolescents preferring self-study was more in rural as compared to urban, whereas adolescents preferring discussion with friends. Group of friends were more in urban as compared to rural. The difference between the two groups was significant.

\section{Influence of Teachers on Studies}

$70.4 \%$ of rural and $57 \%$ of urban adolescents felt teachers influence positively.

\section{Favourite Subject and Teacher}

Among science students, it was physics subject and teacher and among arts/ education/ commerce students it was economics subject and teacher which were favourites. By this, one can conclude that the teaching skills of particular teachers have the greatest influence on students.

\section{Ambition in Life}

Present study showed that most of the urban adolescents preferred to become professionals, but rural adolescents preferred administrative services and teaching.

\section{Safety at College}

Majority felt safe at college, which is consistent with MKC Nair study.

\section{Co-Education}

The two groups differed significantly in this aspect. Majority of urban adolescents $(74.2 \%)$ felt it is good, but only $49.4 \%$ of rural adolescents felt so.

\section{Attitudes towards Nutritional Aspects Mean Nutrient Intake}

Though the mean caloric and protein intakes were less than the recommended daily allowances for both the groups of adolescents, the mean nutrient intake of urban adolescents were better than the rural.

\section{Number of Main Meals per Day}

Majority of rural adolescents had 3 main meals per day, while majority of urban adolescents had $<2$ meals per day. This is because of tightly occupied schedule resulting in change in the timing of meals and lack of family socialisation as a result of urbanisation.

\section{Snacks}

Snacking was more common among urban adolescents than rural adolescents, because of easy availability and affordability in urban areas.

\section{Duration between each Meal}

Irrespective of the locality, the duration between each meal was 6 - 8 hours in most of the adolescents.

\section{Type of Food He/ She Likes}

Vegetarians were more in both the groups as compared to nonvegetarians. In our study, vegetarians were more in urban than in rural set-up in contrast to Saroj Dahia (2003) study, in which vegetarians were more in rural than in urban areas.

\section{Possible Reasons for preferring Vegetarian Diet}

- Concern for animal welfare.

- Desire to improve the quality of their diet and thus the nutritional health.

\section{Whether Consumes Milk Everyday}

The consumption of milk was more in urban adolescents as compared to rural. In Saroj Dahia (2003) studies, the milk consumption was significantly higher than the present study.

\section{Eating Cheese, Yogurt and Dairy Products}

These products were favourites of both the groups though.

\section{Eating Broccoli, TOFU, Oranges, Legumes}

Eating of these food products was significantly more common in urban adolescents than in rural. This was due to availability, affordability and awareness about nutrition.

\section{Taking Vitamins/ Mineral Supplements}

Only $2 \%$ of adolescents from each group were taking vitamin/mineral supplements. This is because adolescent period is the healthier period, which results in few visits to the consultants.

\section{Eating Chats including Pizza}

Majority of adolescents from both the groups were in the habit of eating chats/ pizza.

\section{Eating Outside}

Regularly eating outside was observed in $24.2 \%$ of urban and $11.2 \%$ of rural adolescents, whereas $38.2 \%$ of rural and $28.4 \%$ of urban adolescents never went out for food.

\section{Thinking too much about Foods and Choices of Foods}

Significantly, more number of urban adolescents were choosy about their foods and its choices as compared to rural.

\section{Care about Controlling Weight}

Urban adolescents were much concerned about controlling weight than rural.

\section{CONCLUSION}

- Academic underachievement was more common in rural adolescents than in urban adolescents because of the fact that facilities for studies and motivation were lacking, and factors that disturbs studies were common in rural areas.

- Nutritional status and dietary practices and beliefs of the two groups differs significantly, since the consumption of nutrients was significantly lower than RDA in both the groups. There is an urgent need for educating the adolescents regarding their redistribution of nutrients and suitable ways to meet their needs for maintaining their health and better nutritional status. 


\section{REFERENCES}

[1] Bott S. Towards adulthood: exploring the sexual and reproductive health of adolescents in South Asia. Geneva, World Health Organization, 2003: p. 110-22.

[2] Cutler EM, Bateman MD, Wollan PC, et al. Parental knowledge and attitudes of Minnesota laws concerning adolescent medical care. Paediatrics 1999;103(3):5827.

[3] Dev NP, Neena R. Adolescent health and development. Chapter - 25. In: Ghai OP, Gupta P, Paul VK, eds. Ghai essential paediatrics. $6^{\text {th }}$ edn. New Delhi: CBS Publishers 2004: p. 71-80.
[4] Mary R, Malcolm L. Pediatrics and child health. $3^{\text {rd }}$ edn. London: Blackwell Sciences Ltd., 1999: p. 345-6.

[5] Education in The state of the Worlds Children (UNICEF), 1999.

[6] Rao AR, Thirumagal V. Drug addiction in adolescents: prevention and treatment issues. Indian Journal of Practical Pediatrics IAP 1998;6(1):27-35. 